\title{
Influence of electric conductivity management on greenhouse tomato yield and fruit quality
}

\author{
Martine DoRAIS $^{\mathrm{a}, \mathrm{b} *}$, Athanasios P. PAPADOPOUlOS ${ }^{\mathrm{a}}$, André GosSELIN $^{\mathrm{b}}$ \\ ${ }^{a}$ Greenhouse and Processing Crops Research Centre, Agriculture and Agri-Food Canada, Harrow, ON, N0R 1G0, Canada \\ ${ }^{\mathrm{b}}$ Centre de Recherche en Horticulture, Université Laval, Sainte-Foy, QC, G1K 7P4, Canada
}

(Received 3 August 2000; revised 6 February 2001; accepted 26 February 2001)

\begin{abstract}
The osmotic and ionic effects of the electrical conductivity (EC) of the nutrient solution and its interactions with climatic factors and cultural practices on tomato yield and fruit quality are reviewed. Adjusting the salinity of the nutrient solution allows growers to modify water availability to the crop and hence improve fruit quality. At some point, however, increases in salinity limit marketable yield. Under high ECs, fruit size is inversely related to EC while the dry matter content of the fruit is linearly increased by the EC. The exact rate of yield decline varies with interactions between cultivars, environmental factors, composition of the nutrient solution, and crop management. According to different studies and growth conditions, salinities higher than $2.3-5.1 \mathrm{mS} \cdot \mathrm{cm}^{-1}$ result in an undesirable yield reduction, while ECs of 3.5-9.0 mS $\mathrm{cm}^{-1}$ improve tomato fruit quality. Manipulating the indoor climate such as humidity, temperature and ambient $\mathrm{CO}_{2}$ level may offset the negative effect of high salinity on yield and fruit quality such as blossom-end rot. The light intensity received by the plant directly affects the quantity of photoassimilates available to the fruit, it also increases their sugar: acid ratio, and influences the transpiration rate and the water uptake by the plant, which in turn, affect the EC around the root. Increasing the $\mathrm{EC}$ with $\mathrm{NaCl}$ reduces titratable acids, potassium and nitrogen in the fruit but also increases their sodium content. $\mathrm{NaCl}$ enhances the sweetness of tomato fruit and improves the overall flavour intensity. Depending upon the composition of the saline solution, ion toxicities or nutritional deficiencies may arise because of a predominance of specific ion or competition effects among cations and anions. Keeping the proper nutrient levels and ratios between all the nutrients in the root environment for each growth stage of a crop should be targeted in order to achieve high yields and high quality products throughout the cropping season. Several EC and fertigation management regimes could improve fruit quality and are presented in this review.
\end{abstract}

\section{Lycopersicon esculentum / tomato / electrical conductivity / salinity / fruit quality / greenhouse}

Résumé - Influence de la régie de la conductivité électrique de la solution nutritive sur le rendement et la qualité de la tomate de serre. Cette revue de littérature porte sur les effets osmotiques et ioniques de la conductivité électrique (CE) de la solution nutritive et de ses liens avec les facteurs climatiques et culturaux sur le rendement et la qualité de la tomate de serre. L'ajustement de la salinité de la solution nutritive permet aux producteurs de modifier la disponibilité en eau pour la plante de façon à contrôler la qualité des fruits. Cependant, des salinités élevées affectent le rendement vendable. Sous une haute CE, le calibre des fruits est inversement relié à la $\mathrm{CE}$ alors que le contenu en matière sèche des fruits augmente linéairement avec la CE. Le taux de réduction du rendement varie selon les interactions entre la $\mathrm{CE}$ et les cultivars, les facteurs environnementaux, la composition de la solution nutritive, et la gestion de la culture. Selon différentes études et conditions de croissance des plants, une CE plus élevée que $2.3-5.1 \mathrm{mS} \cdot \mathrm{cm}^{-1} \mathrm{entrâ}-$ ne une baisse de rendement alors qu'une salinité de $3.5-9.0 \mathrm{mS} \cdot \mathrm{cm}^{-1}$ améliore la qualité des fruits. La manipulation du climat de la serre (humidité relative, température, niveau de $\mathrm{CO}_{2}$ ambiant) peuvent compenser les effets négatifs engendrés par de hautes salinités sur le rendement et la qualité des fruits. L'intensité lumineuse reçue par la plante affecte directement la quantité de photoassimilats disponibles pour les fruits, accroît leur rapport sucre : acide, influence les taux de transpiration et d'absorption de l'eau par les plants,

Communicated by Christian Gary (Avignon, France)

* Correspondence and reprints

doraisma@em.agr.ca 
lesquels influencent la $\mathrm{CE}$ de la zone radiculaire. L'accroissement de la salinité par l'ajout de $\mathrm{NaCl}$ réduit le contenu en acides titrables, en potassium et en azote des fruits et augmente leur contenu en sodium. Le NaCl accroît la qualité gustative des fruits et la perception d'une saveur plus sucrée. Selon la composition de la solution nutritive, des déficiences ou toxicités nutritionnelles peuvent survenir suite à une prédominance d'ions spécifiques ou à une compétition parmi les cations et les anions. De façon à obtenir des rendements élevés de très grande qualité tout au long de la saison de production, un équilibre entre les éléments nutritifs de la rhizosphère doit être préservé pour chacun des stades de croissance. Cet article présente plusieurs stratégies de gestion de la CE afin d'améliorer la qualité de la tomate de serre.

Lycopersicon esculentum / tomate / conductivité électrique / salinité / qualité des fruits / serre

\section{INTRODUCTION}

Tomato (Lycopersicon esculentum Mill.) is one of the most important horticultural crops in the world. In terms of human health, tomato fruit is a major component of daily meals in many countries and constitutes an important source of minerals, vitamins, and antioxidant compounds. In recent years, the interest has been focused on the organoleptic and health aspects of tomato fruit. Recent studies on consumer habits for fresh vegetables in North America have shown that taste and aroma are the most important factors in the selection of a product. Tomato fruit quality for fresh consumption is determined by appearance (colour, size, shape, freedom from physiological disorders and decay), firmness, texture, dry matter, and organoleptic (flavour) and nutraceutic (health benefit) properties. The organoleptic quality of tomato is mainly attributed to its aroma volatiles, sugar and acid content, while its mineral, vitamin, carotenoid and flavonoid content define the nutraceutical quality. Fruitiness, which best describes overall tomato flavour, depends on growing conditions and cultivar, and was linked to increased levels of reducing sugars and decreased glutamic acid content [26, 27]. Sweetness and sourness are each influenced by the amount of acids and sugars present [125]. Carotenoids, in addition to their role in fruit colouring are an excellent source of vitamin $\mathrm{A}$ and antioxidizing agents, and thus play an important role in preventing cancer and heart diseases $[111,112]$. Flavonoids (diphenylpropanes; $\mathrm{C}_{6}-\mathrm{C}_{3}-\mathrm{C}_{6}$ ) are antimutagenic and anticarcinogenic [63, 182]. In addition, tomato fruit is relatively rich in other potentially beneficial compounds such as ferulic, chlorogenic and cafeic acids, and have small quantities of vitamin $\mathrm{E}$ and glycoalkaloids [30, 77]. Postharvest durability and fruit safety are also very important quality criteria for product distribution and marketing [76, 106]. Improvement of fruit quality is an urgent issue for greenhouse growers who want to meet the ever-increasing demand of consumers in a highly competitive fresh market [86], and EC management constitutes an important strategic tool $[19,31,35,51,94,101,119,120,132-135,147,168$, $169,173,179,184]$.
Under northern European and American growing conditions, nearly all greenhouse vegetable crops are produced on soilless media. With the upcoming phase out of methyl bromide under the Montreal Protocol, soilless culture will become almost mandatory. For environmental reasons, re-use of drained irrigation water is desirable and will become a common practice in the near future. The recirculation of the nutrient solution, however, leads to accumulation of nutrients and high salinity, which requires a flushing rate of $30 \%$ or more of the nutrient solution [171]. Usually, nutrient solutions used for growing tomato plants in soilless systems have a salinity level in the range of $25 \mathrm{mM}$ (closed irrigation system) to 40-75 mM (open irrigation system) total ion concentration (equivalent to an EC of $1.6-5.0 \mathrm{mS} \cdot \mathrm{cm}^{-1},[179$, 188]. Adjusting the EC generally allows greenhouse growers to modify plant water availability and to maintain a balance between vegetative and generative parts of a crop plant $[96,128]$. High EC during the early phase of establishment can be used to build strong cell walls in plants. However, the requirements for different ECs of the nutrient solution in relation to optimum yield and quality sometimes differ and depend on the interactions between cultivar [101, 171], environmental factors and cultural practices $[50,99,109,168,171]$. Interactions between these parameters may explain the contradictory results found in the scientific literature and increase the challenge in attempting to synthesize all different studies, with different objectives and temporal levels. It is largely accepted, however, that high ECs improve the organoleptic fruit quality but may reduce fruit size and marketable yield $[19,31,35,52,53,94,101,119,120$, $132-135,146,159,164,167-169,173,184]$. Unlike growth and yield studies, few experiments have been conducted on the influence of salinity on nutraceutic properties of tomato.

Decline in both quantity and quality of irrigation water in many countries is also responsible for the use of higher ECs. The relations between salinity and mineral nutrition of horticultural crops are extremely complex [75]. Under high ECs, crop performance may be adversely affected by a water deficit arising from the low water potential of the nutrient solution (osmotic effect), 
and by salinity-induced nutritional disorders associated with the excessive ion uptake (e.g. $\mathrm{Na}^{+}, \mathrm{Cl}^{-}$) or nutrient imbalance by nutrient availability, competitive uptake, transport or partitioning within the plant (ionic effect). In the first case, salinity decreases water availability and water uptake and thus reduces root pressure-driven xylem transport of water and solutes [126]. Both the rate of supply of water and mineral nutrients to the shoot becomes restricted under these conditions.

Previous reviews have discussed the effects of salinity on plant growth and fruit production in relation to salt tolerance [44, 163], mineral nutrient interactions [75] or described fruit components and quality for field and processing tomato [34, 46, 68, 69, 138, 155, 172, 174, 175]. In this paper, we focus on the osmotic and ionic influence of the EC of the nutrient solution on greenhouse tomato yield and fruit quality at the whole-plant level, with emphasis on the current state of knowledge of the interactions between salinity and climatic factors and cultural practices. We conclude this review by identifying several fertigation management practices that could improve greenhouse fruit quality without yield reduction.

\section{EFFECT OF ELECTRICAL CONDUCTIVITY OF THE NUTRIENT SOLUTION ON FRUIT DEVELOPMENT AND YIELD}

\subsection{Flower set and fruit growth rate}

For the North American markets, consumers prefer large tomato fruit size $(200 \mathrm{~g})$. Increasing the EC of the nutrient solution can substantially reduce the rate of fruit growth and the final fruit size by an osmotic effect. High salinity lowers water potential in the plant, which will reduce the water flow into the fruit and therefore the rate of fruit expansion [103]. This osmotic effect varies according to the light intensity received by the plant. For example, at the beginning of a new crop (grown under low light intensity), an EC of $17 \mathrm{mS} \cdot \mathrm{cm}^{-1}$ reduced the fruit growth rate by only $25 \%$ compared to a standard EC $\left(3 \mathrm{mS} \cdot \mathrm{cm}^{-1}\right)$ [148]. During the summer season (grown under high light intensity), however, the fruit growth rate was greatly reduced by an elevated EC. Cuartero and Fernandez-Munoz [44] suggested that fruit from salt-treated plants $(150 \mathrm{mM} \mathrm{NaCl})$ grow normally during the cell division phase while during the cell expansion phase deleterious effects of salts are observed as a consequence of a low water content in the fruit. Ehret and Ho [55] observed that tomato grown at high salinity $\left(17 \mathrm{mS} \cdot \mathrm{cm}^{-1}\right.$ compared to $\left.2 \mathrm{mS} \cdot \mathrm{cm}^{-1}\right)$ showed reduced day-time growth rate of fruit, while the growth rate at night was similar for fruit grown at both low and high ECs. The rate of blossom production and the length of the fruit-growing period was not influenced by high ECs prevailing under greenhouse growth conditions. Under excessive salinity $\left(15 \mathrm{mS} \cdot \mathrm{cm}^{-1}\right)$, Adams and Ho [12] observed that fruit set on the upper trusses is reduced. The long term effect of high salinity on fruit set might be explained by a lower number of pollen grains per flower rather than pollen fertility [78]. Depending on the temperature, the tomato cultivar, the severity of salinity and the duration of salinisation, the number of trusses per plant as well as the number of flowers per truss might be influenced by extreme salinity conditions $[42,70,78,156,179]$ which are normally not found under greenhouse soilless growing system.

\subsection{Photosynthesis, dry matter accumulation and partitioning}

Under high ECs, high light intensity and vapor pressure deficit (VPD) levels have a negative synergistic effect on photosynthesis [195], which might affect the photoassimilate availability to the fruit, and then the fruit yield and quality. Abnormal photosynthetic responses to irradiance, such as hysteresis, photosynthetic depression under high radiation and oscillation, are induced or promoted by high ECs [192]. On the other hand, neither the fruit strength (sink activity), nor the quantity of photoassimilates imported by the fruit were affected by a high $\mathrm{EC}$ and by a reduction in water absorption [57, 84, 85]. Under an EC of $6 \mathrm{mS} \cdot \mathrm{cm}^{-1}$, biomass and dry matter partitioning among fruit (52\%), vegetative parts (44\%) and roots $(4 \%)$ were not affected [57, 84]. Nevertheless, an EC of $10 \mathrm{mS} \cdot \mathrm{cm}^{-1}$ reduced plant dry weight by $19 \%$ as compared to an EC of $2 \mathrm{mS} \cdot \mathrm{cm}^{-1}$, but did not necessarily influence dry matter partitioning [57]. An EC of $17 \mathrm{mS} \cdot \mathrm{cm}^{-1}$, however, slightly reduced dry matter distribution to the fruits. Consequently, yield reductions under high EC conditions were rather proportional to plant growth reductions [57].

De Koning [47] reported a $0.17 \%$ increase in fruit dry matter content following an increase of EC by one unit. Starch accumulation in the fruit [132] and the activity of the sucrose synthase enzyme were intensified when plants were cultivated under high salinity [84, 85]. Ehret and Ho [57] reported that carbohydrate partitioning between starch and soluble sugars can be influenced by the osmotic potential of young fruit. Under saline conditions, the starch concentration in the fruit can account for as much as $40 \%$ of dry matter. Recently, Gao et al. [67] have shown that $\mathrm{NaCl}$ salinity $(0,50$ or $100 \mathrm{~mm} \mathrm{NaCl})$ enhanced the transport of ${ }^{14} \mathrm{C}$-assimilates from the pulse leaf to adjacent fruits and the diversion of ${ }^{14} \mathrm{C}$ label to the starch fraction of the fruit; it also extended the period 
of starch accumulation in developing fruit. These authors suggested that sucrose unloading to the developing fruit is enhanced under high salinity by increased starch, which will be later hydrolysed back to soluble hexoses during fruit maturation, with the resulting improvement of fruit quality. Thus, under saline conditions, both a higher concentration of sucrose in the leaves (higher activity of sucrose phosphate synthase, lower acid invertase activity) and a faster rate of starch synthesis in the immature fruit (higher activity of ADP-Glc-Ppase) may partially constitute a mechanism responsible for a higher sugar content in the mature fruit. For salt-stressed fruit, in spite of a higher sucrolytic activity (higher neutral invertase and sucrose synthase activities) than non-saltstressed fruit, Balibrea et al. [21] measured a higher sucrose content.

\subsection{Yield}

At ECs of $4.6-8 \mathrm{mS} \cdot \mathrm{cm}^{-1}$ fruit yield was reduced because of a reduction in fruit size, whereas an EC of 12 $\mathrm{mS} \cdot \mathrm{cm}^{-1}$ reduced both the number and size of fruit $[7$, 71, 80]. At high ECs, decline of fruit number explains the main proportion of yield reduction [43, 179]. According to different studies and growth conditions, salinities higher than $2.3-5.1 \mathrm{mS} \cdot \mathrm{cm}^{-1}$ result in an undesirable yield reduction $[52,128,169,180]$, while ECs of $3.5-9.0 \mathrm{mS} \cdot \mathrm{cm}^{-1}$ improve tomato fruit quality. Table I summarises the recommended EC thresholds by various authors in relation to tomato fruit quality, yield and yield reduction. For field cultivation, models of yield response of tomato plants as a function of root-zone salinity have been made [123, 178] but they are not applicable to soilless cultivation (inert substrate) because there is a buffer soil effect in the field and thus a delay in the build up of salinity in the soil.

The effects of high salinity on fruit yield vary according to the cultivar and not all tomato cultivars reduce their fruit size to the same extent [44] or are affected at the same level by blossom-end rot (BER) [12, 13, 23, 44, $86]$ or fruit cracking $[1,2,36]$. In general, the yield [28] and individual fruit weight [42] of cultivars with smaller fruit size would be less affected by high salinity than cultivars with larger fruit. Thus, growing smaller-size cultivars could be advantageous when available water is highly or moderately saline [44].

\section{EFFECT OF ELECTRICAL CONDUCTIVITY OF THE NUTRIENT SOLUTION ON FRUIT QUALITY}

\subsection{Physiological disorders}

Fruit cuticle is thicker and more resistant at high salinity while fruit turgor pressure [180] and firmness [181] are reduced resulting in a lower susceptibility to fruit cracking [169]. Increasing the EC by 1.3 times of the control EC (2.6-4.6 compared to $\left.2.0-3.5 \mathrm{mS} \cdot \mathrm{cm}^{-1}\right)$ in a greenhouse tomato spring crop reduced the incidence of fruit with cracking by $68 \%$ [32]. Despite the fact that $\mathrm{CO}_{2}$ enrichment reduces stomatal conductance and transpiration, improves water-use and light-use efficiency [54] and increases photosynthesis rate, a high supply of photoassimilate to the fruit under $\mathrm{CO}_{2}$

Table I. Recommended EC thresholds by various authors in relation to tomato fruit quality, yield and yield reduction.

\begin{tabular}{lccc}
\hline Authors & $\begin{array}{c}\text { Quality threshold* } \\
\left(\mathrm{mS} \cdot \mathrm{cm}^{-1}\right)\end{array}$ & $\begin{array}{c}\text { Yield threshold } \\
\left(\mathrm{mS} \cdot \mathrm{cm}^{-1}\right)\end{array}$ & $\begin{array}{c}\text { Yield reduction } \\
\text { EC interval }\end{array}$ \\
\hline Massey et al. [128] & & 4.0 & \\
Mizrahi et al. [134] & 6.0 & 3.5 & 6 \\
Gormley and Maher [71] & 3.5 & 5.0 & $2.0-5.0$ \\
Gough and Hobson [73] & 5.0 & 3.0 & \\
Adams [7] & 5.2 & $2.5-2.9$ & $2.3-7.6$ \\
Sonneveld and Van Der Burg [191] & & & 1 \\
Verkerke and Schols [180] & & & 6 \\
Ho [85] & $2.9-5.6$ & $2.6-5.1$ & 10 \\
Dorais et al. [52] & $3.0-4.6$ & $2.1-3.3$ & $6.0-9.0$ \\
Hao et al. [82] & & & 5.0 \\
\end{tabular}

* Threshold: EC level at which or within a range under which tomato fruit quality or yield is optimum. 
enrichment $[65,136,196,197]$ associated with a high uptake of water under low EC [55, 103] increase the fruit susceptibility to cracking. The use of high EC may also lead to an increase in fruit colour indices [169], in the proportion of class 1 fruit (from 76 to 93\%; [7]), as well as in a reduction of uneven ripened fruit [169].

Generally, the number of fruit affected by BER increases with salinity $[12,48,86,91,92,190]$. BER is a physiological disorder which occurs at the youngest stage of the fruit development (7-21 days after anthesis) and visible symptoms begin with slight browning tissue at the distal part of the placenta which progressively invades the adjacent locular content as well as the pericarp [91, 190]. Internal BER (also called "black seeds") may be present and black necrotic tissue is restricted to the adjacent parenchyma tissue around the young seeds and the distal part of the placenta [12]. These fruits generally stop growing and start ripening earlier. Lack of coordination between accelerated cell enlargement, due to high import of assimilates, and inadequate supply of calcium, caused by poor development of xylem within the fruit, is generally linked to fruit susceptibility to BER $[12,23,24,56,84,92,93]$. Cultivars with small fruit size, good development and distribution of the xylem towards the distal end of the fruit [23], high $\mathrm{Ca}^{2+}$ uptake efficiency and distribution within the fruit will be less susceptible to BER [13]. For instance, BER-sensitive cultivar "Rambo" had $12 \%$ of fruits with BER at $2.4 \mathrm{mS} \cdot \mathrm{cm}^{-1}$ and $53 \%$ at $13.6 \mathrm{mS} \cdot \mathrm{cm}^{-1}$ while for "Daniela", these figures were $3 \%$ and $11 \%$, respectively [44]. Recently, Willumsen et al. [190] reported that the incidence of both external and internal BER strongly depends on the ion activity $\left(\mathrm{a}\right.$, in $\left.\mathrm{mol} \cdot \mathrm{L}^{-1}\right)$ ratios between $\mathrm{K}$ and $\mathrm{Ca}+\mathrm{Mg}\left(\mathrm{a}_{\mathrm{K}} / \sqrt{\left[\mathrm{a}_{\mathrm{Ca}}+\mathrm{a}_{\mathrm{Mg}}\right]}\right)$ and between $\mathrm{Mg}$ and $\mathrm{Ca}\left(\mathrm{a}_{\mathrm{Mg}} / \mathrm{a}_{\mathrm{Ca}}\right)$ in the root zone at both moderate (3 to $\left.6 \mathrm{mS} \cdot \mathrm{cm}^{-1}\right)$ and high (6 to $\left.12 \mathrm{mS} \cdot \mathrm{cm}^{-1}\right)$ salinity levels. The higher the activity ratios, the higher the risk of BER due to a lower uptake of $\mathrm{Ca}^{2+}$ and a reduced availability of $\mathrm{Ca}^{2+}$ in the fruit tissue caused by increased concentration of organic acids in the fruit juice. By maintaining the ion activity ratios at optimum levels (about 0.1 for the first ratio and 0.2 to 0.4 for the second) these authors reported that it is possible to avoid or reduce the occurrence of BER when salinity of the root zone is increased to improve the fruit organoleptic quality. The ideal EC of the nutrient solution, relative to preventing BER in the greenhouse tomato, is currently 2.0 to $2.5 \mathrm{mS} \cdot \mathrm{cm}^{-1}$, with a calcium concentration of $7 \mathrm{mM}$ [48]. However, these levels are not optimal for other tomato quality attributes such as fruit flavour, fruit firmness and fruit cracking. BER was also related to the expression of some genes under conditions of stress [141]. Additional research of the ion activity ratios in relation to gene expression is needed for a clear understanding of this disorder.

\subsection{Organoleptic and nutraceutic properties}

Concentrations of dry matter, soluble solids, fructose, glucose, titratable acids, volatile compounds, minerals, carotene and vitamin $\mathrm{C}$ in fresh fruit increase with increasing salinity $[5,51,52,71,94,96,134,154,165$, 168, 169, 173]. Gough and Hobson [73] found that for cluster tomato grown in NFT at EC's of 3.0, 5.0 and $8.0 \mathrm{mS} \cdot \mathrm{cm}^{-1}$, the most flavourful fruit was produced under an EC of $5 \mathrm{mS} \cdot \mathrm{cm}^{-1}$. For Daniela and Rambo cultivars, Cuartero and Fernandez-Munoz [44] reported a $10.5 \%$ increase in total soluble solids per additional $\mathrm{mS} \cdot \mathrm{cm}^{-1}$ above $2 \mathrm{mS} \cdot \mathrm{cm}^{-1}$ while titratable acidity increased from around 75 to $290 \mathrm{meq} \cdot \mathrm{L}^{-1}$ when salinity increased from 2 to $14 \mathrm{mS} \cdot \mathrm{cm}^{-1}$. Increasing EC from $2.3-4.5$ to $2.6-5.1 \mathrm{mS} \cdot \mathrm{cm}^{-1}$ increased fruit EC by $10-21 \%$, which is related to better flavour intensity of tomato fruit and higher consumer satisfaction [53]. Nevertheless, very high ECs $\left(12 \mathrm{mS} \cdot \mathrm{cm}^{-1}\right)$ reduced the fruit content in sugars and acids [6] and thus, fruit flavour. Cultivars do not have the same response to salinity, consequently no general recommendation could be made for all types of tomato. For example, Auerswald et al. [19] recently observed that the sensory changes caused by increasing nutrient solution EC from 1.0 to 6.0 $\mathrm{mS} \cdot \mathrm{cm}^{-1}$ with macronutrients, improved the quality of the conventional round cultivar "Counter" but not that of the longlife type "Vanessa". For "Vanessa", higher EC led to a much stronger intensity of negative flavour attributes such as "mouldy", "spoiled sweetish", "bitter", and of the aftertaste attributes such as "mouldy" and "burning", which contribute to the off-flavour. In contrast, for "Counter", the more intense fruity flavour, juiciness and firmness under high EC were judged by consumers to improve fruit quality. It is obvious that $\mathrm{CO}_{2}$ enrichment improves both the production and fruit quality [183]. Plants grown under conditions of salt stress have been reported to show a higher growth response to elevated $\mathrm{CO}_{2}$ than non-stressed plants [118, 161]. Recently, Li et al. [119] observed that high $\mathrm{CO}_{2}$ (1200 ppm) slightly increased fruit quality (total sugars, soluble solids) of tomato plants grown under high salinity $\left(5.2\right.$ and $\left.7.0 \mathrm{mS} \cdot \mathrm{cm}^{-1}\right)$. These authors suggested for a salt tolerant tomato cultivar that a combined utilisation of high salinity and $\mathrm{CO}_{2}$ supplementation may enable the production of high-quality fruits without incurring all the inevitable yield losses associated with salt treatment. 


\subsection{Shelf-life}

Fruit shelf life is one component of the postharvest fruit quality and it is dependent on pre-harvest factors such as the fertigation management. Several studies have shown that increasing the EC of the nutrient solution: (1) may increase fruit shelf-life $[117,169]$ because such fruit has thicker and more resistant cuticle [180]; (2) make fruit less susceptible to cracking [32] and gold specks which reduce shelf life [22, 83, 100, 189]; and (3) limit the massive influx of water into the fruit which might damage the cell (watery tomato) and reduce their shelf life. Nevertheless, these effects depend of the interactions between EC and growth parameters and are not conclusive under moderate ECs. For example, we did not find throughout two growing seasons of greenhouse tomato any salinity effect on fruit shelf life expressed by their color and firmness when ECs were increased from $1.8-3.5$ to $2.9-5.6 \mathrm{mS} \cdot \mathrm{cm}^{-1}$ (data not published). ECs of $8 \mathrm{mS} \cdot \mathrm{cm}^{-1}$, however, were shown to yield fruit more resistant to mechanical manipulation, while a much faster fruit ripening and a reduction in fruit shelf life have been reported when plants were grown under extreme salinity levels $\left(103 \mathrm{~mm} \mathrm{NaCl}, 11.4 \mathrm{mS} \cdot \mathrm{cm}^{-1}\right)$ [133]. For long shelf life field tomato cultivars $(\operatorname{rin} \mid+)$, salinity causes no alteration in shelf life [44], while high salinity provided by $\mathrm{NaCl}$ or $3: 1 \mathrm{NaCl}: \mathrm{CaCl}_{2}\left(7.5 \mathrm{~g} \cdot \mathrm{L}^{-1}\right)$ may induce ripening in the non-ripening mutants [18]. Special care should be taken during the handling of fruit grown under high salinity as damages due to picking, packing and transport cause higher $\mathrm{CO}_{2}$ and ethylene production compared to fruit grown under low ECs [94].

\section{EFFECT OF ELECTRICAL CONDUCTIVITY OF THE NUTRIENT SOLUTION ON TRANSPIRATION AND WATER UPTAKE}

The flavour increase under high salinity may be associated with an osmotic effect: reduction in water absorption by roots because of a decrease in the osmotic potential $(\Psi s)$ of the nutrient solution combined with an increase in the resistance of the xylem transport system inside the fruit. Consequently, excessive salinity can reduce $\mathrm{Ca}^{2+}$ absorption $[9,87,88,131]$, the number of xylem vessels and the ionic exchange capacity [23], and the tomato leaf water potential [160]. For instance, Ehret and Ho [55] reported reduced water absorption capacity per plant (from 415 to $98 \mathrm{ml}$ ) in young tomato plants when the EC was increased from 2 to $17 \mathrm{mS} \cdot \mathrm{cm}^{-1}$ and that the absorption rate of $\mathrm{Ca}$ was reduced by $87 \%$. A strong linear relationship $(r=0.97)$ between EC of the nutrient solution and tomato plant water absorption has been demonstrated [170]. For other species, it has been suggested that root permeability decreased under salt stress and might explain the reduction of water uptake $[64,152]$, but this explanation is not conclusive for tomato grown under $0-200 \mathrm{mM} \mathrm{NaCl}$ [158, 162]. Tomato fruit has a very low transpiration rate and only around $15 \%$ of the water input comes via the xylem [90]. Therefore, reduction in xylem development would explain a small part of the reduction in fruit weight of salt-treated plants [44].

Recently, Kläring and Schwarz [107] showed that diurnal adjustment of the concentration of the nutrient solution, as a function of the greenhouse VPD, reduced the percentage of fruit with BER. High humidity (low VPD) during the day reduces canopy transpiration and movement of $\mathrm{Ca}^{2+}$ into the leaves [74]. Hence, more of the absorbed $\mathrm{Ca}^{2+}$ remains available for the fruit [14]. Similarly, Stanghellini et al. [171] showed that manipulating indoor climate such as humidity (potential evaporation), may offset the effect of high salinity on yield and fruit quality. Under high salinity $\left(10 \mathrm{mS} \cdot \mathrm{cm}^{-1}\right)$, they observed that depressing plant transpiration by $35 \%$ under the same solar radiation reduced the incidence of BER from $20 \%$ to $2 \%$ of the total yield, and might enlarge fruit size, thereby improving fruit quality and yield value. Under moderate salinity, however, we observed that higher humidity (VPD of $0.2 \mathrm{kPa}$ compared to $0.4 \mathrm{kPa}$ ) did not offset the fruit size reduction when EC increased from $1.8-3.5$ to $2.9-5.6 \mathrm{mS} \cdot \mathrm{cm}^{-1}$ [52]. Low VPD did not affect the enhanced organoleptic quality of fruit grown under these high EC levels.

\section{EFFECT OF ELECTRICAL CONDUCTIVITY OF THE NUTRIENT SOLUTION ON NUTRIENT UPTAKE, TRANSLOCATION AND PARTITIONING}

For tomato, it was found that the highest water absorption was obtained at low EC values while the nutrient uptake was found to be the highest at high EC values. Variations between water and specific ion uptake may cause nutrient deficiency or salt stress at the root level, thereby potentially reducing yield and product quality [109, 185]. Using models for photosynthesis and transpiration, Kläring et al. [108] reported that the influence of global radiation on $\mathrm{K}^{+}$: water uptake ratio is small. In the early stage of plant development, high $\mathrm{Na}^{+}$ and $\mathrm{Cl}^{-}$concentrations (up to $3 \mathrm{mS} \cdot \mathrm{cm}^{-1}$ of $\mathrm{NaCl}$ ) in the nutrient solution did not affect adversely cation uptake such as $\mathrm{K}^{+}, \mathrm{Ca}^{2+}$, and $\mathrm{Mg}^{2+}$ even if we observed $\mathrm{Na}^{+}$ accumulation [52]. Under different growing conditions, increasing the salinity $(\mathrm{NaCl})$ from 3 to 5.5 and $8 \mathrm{mS} \cdot \mathrm{cm}^{-1}$ reduced $\mathrm{K}^{+}$uptake by $27 \%$ and $36 \%$, respectively, while it caused a less important reduction in the 
uptake of water (7 and 15\%) and $\mathrm{Ca}^{2+}(5$ and $15 \%)$ [14]. At the root level, previous studies showed that an increase in root temperature up to $24{ }^{\circ} \mathrm{C}$ increased $\mathrm{P}, \mathrm{K}$, $\mathrm{Mg}, \mathrm{Ca}, \mathrm{Fe}$, and $\mathrm{Mn}$ content of leaves in tomato with opposite effects on $\mathrm{Na}[72,105]$. Nevertheless, higher root temperature could not offset the yield reduction under low air temperature during the night. Further studies on EC related to ambient temperature would be essential to provide crucial information for any crop management strategies designed to enhance the flavor and health properties of tomato fruit.

Numerous studies have shown that $\mathrm{K}^{+}$concentration in plant tissue, expressed on a dry weight basis, declines as the Na-salinity or as the $\mathrm{Na}^{+}: \mathrm{Ca}^{2+}$ ratio in the root media increases, as a consequence of a competitive uptake process, and results in growth and yield reductions $[122,151,166]$. Potassium is the most prominent inorganic plant solute, and is involved in several metabolic processes such as synthesis of proteins, enzymatic activation (glycolysis, sucrose and starch synthesis, nitrate reduction), membrane transport processes, charge balance and the generation of turgor pressure [33, 60, 61, $97,98,116]$ and the water balance of the plant [126]. The presence of other nutrients also influences the effect of salinity on $\mathrm{K}^{+}$uptake and accumulation. It has been shown that the presence of adequate $\mathrm{Ca}^{2+}$ in the substrate influences the $\mathrm{K}^{+}: \mathrm{Na}^{+}$selectivity by shifting the uptake ratio in favour of $\mathrm{K}^{+}$at the expense of $\mathrm{Na}^{+}$[75].

Nitrogen uptake might also be affected by high $\mathrm{NaCl}-$ salinity. For 21 day-old tomato plants, nitrogen $\left({ }^{15} \mathrm{~N}\right)$ uptake was reduced at -0.6 and $-0.9 \mathrm{MPa}$ osmotic potentials with $\mathrm{NaCl}(140-200 \mathrm{mM} \mathrm{NaCl})$ compared to -0.3 and $-0.03 \mathrm{MPa}$ [153]. Reduction of $\mathrm{NO}_{3}^{-}$uptake might be explained by an interaction between $\mathrm{NO}_{3}^{-}$and $\mathrm{Cl}^{-}$at the site for ion transport [37], and by a severe membrane depolarisation caused by $\mathrm{Na}^{+}$[176] while others attributed the response to salinity on reduced water uptake [114]. High $\mathrm{Na}^{+}$concentration might displace $\mathrm{Ca}^{2+}$ in plant cell membranes, and several physiological disorders might occur under such conditions. For examples, Cramer et al. [40] observed that salinity shifted the $\mathrm{NO}_{3}{ }^{-}$ reduction from the shoot to the root of tomato plant. Martinez and Cerdà [127] reported a reduction in the nitrate reductase activity of tomato leaves with an increase of salinity $(\mathrm{NaCl})$, while Al-Rawahy et al. [16] observed a lower dry matter production and nitrogen uptake under saline stress by $\mathrm{NaCl}$. This can be explained by the interference of $\mathrm{NaCl}$ on the absorption of nitrate by roots or by the inhibition of nitrate transportation from the vacuole to the cytoplasm. High concentrations of $\mathrm{NaCl}(100 \mathrm{mM})$ inhibit the loading of xylem in $\mathrm{NO}_{3}{ }^{-}$and its subsequent transportation to above ground tomato plant tissues [66]. A greater por- tion of $\mathrm{NO}_{3}{ }^{-}$is therefore reduced and assimilated by the roots. The xylem is enriched in amids, asparagine and glutamine. Thus, the PEPcase and glutamine synthetase activity of roots and leaves is higher under an increased salinity.

The interaction between salinity and phosphorus nutrition is highly dependent upon cultivar, plant developmental age, the composition and level of salinity and the concentration of $P$ in the substrate [75]. Some researchers indicate that salinity stress may increase the $\mathrm{P}$ requirement of a tomato crop. Awad et al. [20] found that at $0.1,1.0$, and $10 \mathrm{mM} \mathrm{P}$, the $\mathrm{NaCl}$ concentrations that reduced yields of fruit by $50 \%$ were 58,72 , and $130 \mathrm{mM}$, respectively. Nevertheless, excess $\mathrm{P}$ in a growing medium results in an imbalance that affects the availability, uptake, and utilisation of other essential elements. P enhances the availability and uptake of $\mathrm{Mn}$, but significantly reduces the uptake and utilisation of $\mathrm{Zn}$, and to a limited degree, Fe [104].

The relationship between salinity and micronutrients is complex and salinity may increase, decrease, or have no effect on the micronutrient concentration in the plant depending on the salinity level and composition, and growing conditions [75]. Some studies with tomato indicated that salinity reduced [17], had no effect [15] or increased [124, 139] $\mathrm{Mn}$ in leaf or shoot tissue. Zinc applications have been found to improve growth in saltstressed tomato plants [58], and some studies have shown salinity to increase $\mathrm{Zn}, \mathrm{Fe}$ and $\mathrm{Cu}$ concentration in tomato shoot $[75,110,124,139]$. Very little attention has been directed towards salinity's effect on Mo uptake and accumulation in horticultural crops [75].

Despite the common occurrence of high boron and high salinity in many parts of the world, very little attention has been given to the study of the interaction between the two [62]. For different species, a negative relationship between $\mathrm{B}$ and $\mathrm{SO}_{4}{ }^{2-}$ and $\mathrm{Cl}^{-}$concentrations in tissues has been found [75], suggesting that $\mathrm{SO}_{4}{ }^{2-}$ and $\mathrm{Cl}^{-}$could be responsible for the salinity-induced reduction in tissue $\mathrm{B}$. In addition, high $\mathrm{Ca}^{2+}$ concentration in the substrate decreased B absorption and can induce a B deficiency [79]. Sulphate accumulation generally occurs in closed growing systems. High sulphate levels in the nutrient solution does not directly influence fruit quality, but may affect it indirectly through an increase in salinity and a change in ionic activities [3, 121]. High sulphate concentrations ( $>40.9 \mathrm{mM}$ ) may also affect the absorption of $\mathrm{P}, \mathrm{Ca}$ and $\mathrm{Mg}$ ions and increase the number of fruit affected by BER [121].

The concentration of the phloem mobile elements $(\mathrm{K}$, $\mathrm{P}$ and $\mathrm{N}$ ) does not vary significantly as fruit develops [55]. Nevertheless, increasing the EC of the nutrient 
solution from 2 to $17 \mathrm{mS} \cdot \mathrm{cm}^{-1}$ reduced the fruit phosphorus concentration, increased potassium concentration and had no effect on nitrogen concentration [55]. Difference between cation $\left(\mathrm{K}^{+}\right.$and $\left.\mathrm{Na}^{+}\right)$and anion $\left(\mathrm{Cl}^{-}\right.$ and $\mathrm{SO}_{4}{ }^{2-}$ ) accumulation under high ECs may explain the higher concentration of organic acids. Organic acids play an important role in the maintenance of electro-neutrality of potassium in the fruit $[45,132]$, and a positive correlation between citric and malic acid content in the fruit and potassium content in the substrate was measured [191].

\section{FERTIGATION MANAGEMENT AND ITS RELATIONSHIP TO FRUIT YIELD AND QUALITY}

\subsection{Growing media and irrigation management}

In soilless culture, different growing media are used such as rockwool, coir, peat, tuff, perlite, and sawdust, and each of them show different responses to nutrient solution EC level [193], and will respond more or less rapidly to changes in growing conditions due to daily climatic variations. Using an EC of $2.5 \mathrm{mS} \cdot \mathrm{cm}^{-1}$ in the feed solution and a substrate matric potential setpoint of $-5.0 \mathrm{kPa}$ with daily leaching, may give an average substrate EC of $4.79 \mathrm{mS} \cdot \mathrm{cm}^{-1}$ for the peat and $3.79 \mathrm{mS} \cdot \mathrm{cm}^{-1}$ for the rockwool [143]. After 30 days of EC treatment, the EC of peat substrate irrigated with low salinity treatment $\left(2.3 \mathrm{mS} \cdot \mathrm{cm}^{-1}\right)$ without leaching was enhanced twofold while the high EC treatment $\left(4.5 \mathrm{mS} \cdot \mathrm{cm}^{-1}\right)$ increased peat salinity by more than 4 times which decreased photosynthetic rate and leaf water potential [194]. Thus, the EC of the feed solution, the frequency of irrigation, and the quantity of nutrient solution provided to the plants, needed for a soilless system to keep an appropriate EC level in the root zone, would vary according to the growing media, and would affect yield and fruit quality [132, 150, 177]. Chrétien et al. [32] showed that increasing EC with $\mathrm{NaCl}$ (2.6 to $4.6 \mathrm{mS} \cdot \mathrm{cm}^{-1}$ ), under a 1.15 times higher irrigation regime based on solar radiation, decreased by $25 \%$ the incidence of fruit with gold speck when compared to the control EC (2.0 to $\left.3.5 \mathrm{mS} \cdot \mathrm{cm}^{-1}\right)$. When using the control $\mathrm{EC}$, a higher irrigation regime caused the highest level of fruit deformity, while the lowest irrigation regime $(0.85$ time) reduced it. They concluded that lower EC combined with higher irrigation in the period of high solar radiation (July, August) lead to higher water and mineral absorption, resulting in a better yield but fruit quality was negatively affected. Similarly, Norrie et al. [143] observed that increased water absorption due to a high matric potential setpoint enhanced the percentage of fruit deformity during the fall. High irrigation regime also reduced fruit quality due to a high water content (reduction in soluble sugars, organic acids, vitamins, minerals and volatile compounds) and due to the tendency of fruit to crack $[1,2,129,130,149,150]$. Irrigation based on the potential evapotranspiration (PET) with an EC of 1 and $4 \mathrm{mS} \cdot \mathrm{cm}^{-1}$ according to the PET, increased photosynthetic capacity, plant growth and fruit yield [193]. Although in peat substrate, increasing nutrient solution EC from 1.5 to $3.0 \mathrm{mS} \cdot \mathrm{cm}^{-1}$ could negatively affect the production and nutritional status of tomato plants more than changing irrigation setpoint from -4.5 to $-6.5 \mathrm{kPa}$ [143].

The open irrigation system, in soilless culture, is still the most popular system and at least $10-15 \%$ of the water and nutrients are lost from the root environment during low light period and 30-50\% during the high light period to avoid salt accumulation. Consumers see closed irrigation systems as the solution to the pollution of ground and surface water by free nutrient drainage. However, the successful practice of closed irrigation system requires good knowledge of plant needs for water and nutrients and the application of water and nutrients must follow exactly those needs to avoid nutrient imbalances and excessive EC levels around the roots. For example, $\mathrm{Na}^{+}$and $\mathrm{Cl}^{-}$are absorbed in low concentration by the plant and their accumulation in the root environment may result in an unbalanced nutrient solution and depletion of other nutrients such as $\mathrm{K}^{+}$in a recirculating irrigation system based on an EC controller [188], while a constant nutrient supply will increase the total salt concentration, which may reduce growth and yield or induce physiological disorders [169]. At the same time, a very high input of microelements in a closed irrigation system does not affect the EC but may induce phytotoxicities (Mn, B, Cu, Zn) or deficiencies (Fe) [188].

\subsection{Composition of the nutrient solution}

Keeping the right nutrient levels, ratios between all the nutrients in the solution, and electrical conductivity around the roots for each growth stage of a crop should be achieved for a high yield and quality product. For instance, the $\mathrm{K}^{+}$uptake is strongly related to fruit load [187]. High $\mathrm{Ca}^{2+}: \mathrm{Mg}^{2+}$ ratios might reduce fruit firmness, soluble solids and dry matter content [81], while $\mathrm{NaCl}$ stress decreased leaf water potential, osmotic potential and stomatal conductance, and then marketable yield [29]. The standard nutrient solution for an open irrigation system is $1.2 \mathrm{mM} \mathrm{NH}_{4}, 9.5 \mathrm{mM} \mathrm{K}, 5.4 \mathrm{mM}$ $\mathrm{Ca}, 2.4 \mathrm{mM} \mathrm{Mg}, 16 \mathrm{mM} \mathrm{NO}_{3}, 4.4 \mathrm{mM} \mathrm{SO}_{4}, 1.5 \mathrm{mM}$ $\mathrm{H}_{2} \mathrm{PO}_{4}, 15 \mu \mathrm{M} \mathrm{Fe}, 10 \mu \mathrm{M} \mathrm{Mn}, 5 \mu \mathrm{M} \mathrm{Zn}, 30 \mu \mathrm{M} \mathrm{B}$, $0.75 \mu \mathrm{M} \mathrm{Cu}, 0.5 \mu \mathrm{M} \mathrm{Mo}$, while the nutrient solution for closed irrigation systems contains lower bivalent ion 
concentrations resulting from a higher accumulation rate of bivalent ions in the root environment: $1.0 \mathrm{mM} \mathrm{NH}_{4}$, $6.5 \mathrm{mM} \mathrm{K}, 2.75 \mathrm{mM} \mathrm{Ca}, 1.0 \mathrm{mM} \mathrm{Mg}, 10.75 \mathrm{mM} \mathrm{NO}_{3}$, $1.5 \mathrm{mM} \mathrm{SO}_{4}, 1.25 \mathrm{mM} \mathrm{H}_{2} \mathrm{PO}_{4}, 10 \mu \mathrm{M} \mathrm{Fe}, 10 \mu \mathrm{M} \mathrm{Mn}$, $4 \mu \mathrm{M} \mathrm{Zn}, 20 \mu \mathrm{M}$ B, $0.75 \mu \mathrm{M} \mathrm{Cu}, 0.5 \mu \mathrm{M}$ Mo [188]. The EC of the drip solution is usually lower ( 0.5 to $2.0 \mathrm{mS} \cdot \mathrm{cm}^{-1}$ ) than that of the drain water, and the concentration of nutrients in the growth medium varies according to the water and nutrient uptake. During the high solar radiation period, ECs of the nutrient solution generally range from 1.6 to $2.5 \mathrm{mS} \cdot \mathrm{cm}^{-1}$ while ECs may reach $5 \mathrm{mS} \cdot \mathrm{cm}^{-1}$ under low solar radiation.

For soilless culture, the salinity increase can be achieved by augmenting the macronutrients $\left(\mathrm{NO}_{3}, \mathrm{NH}_{4}\right.$, $\mathrm{K}, \mathrm{Ca}, \mathrm{Mg}, \mathrm{H}_{2} \mathrm{PO}_{4}, \mathrm{SO}_{4}$ ) or by adding $\mathrm{NaCl}, \mathrm{KCl}$ or $\mathrm{CaCl}_{2}$ in the nutrient solution. Increasing the $\mathrm{EC}$ with $\mathrm{NaCl}$ reduces titratable acids, potassium and nitrogen in fruit but increases their sodium and calcium content [7, 10]. The interference of sodium in the absorption and transportation of potassium [113] can explain the reduction in fruit titratable acids. Petersen et al. [154] further explained the effect of salinity source on titratable acid content by an increase of ion activity ratio $\mathrm{a}_{\mathrm{k}} / \sqrt{\left[\mathrm{a}_{\mathrm{Ca}}+\mathrm{a}_{\mathrm{Mg}}\right]}$ in the root zone when major nutrients rather than $\mathrm{NaCl}$ were applied to increase the salinity. This ratio may also explain the considerably reduced fruit yield under a salinity of $12 \mathrm{mS} \cdot \mathrm{cm}^{-1}$ when macronutrients were used to increase the EC as compared to the addition of $\mathrm{NaCl}[6]$. Under these conditions (high levels of macronutrients), the percentage of marketable fruit was only $30 \%$ (35\% of fruit with BER vs. $2 \%$ with $\mathrm{NaCl}$ ), and foliar deficiency, during the summer, in magnesium, boron and iron deficiency period was reported [6]. In contrast to previous studies, Petersen et al. [154] reported that increases in fruit components (dry matter, soluble solids, fructose, glucose, titratable acid, carotene and vitamin C) under increasing salinity are independent of the source of salinity, if it results in only minor changes in the ion activity ratio $\mathrm{a}_{\mathrm{k}} / \sqrt{\left[\mathrm{a}_{\mathrm{Ca}}+\mathrm{a}_{\mathrm{Mg}}\right]}$ and $\mathrm{a}_{\mathrm{Mg}} / \mathrm{a}_{\mathrm{Ca}}$ in the root zone. Little effect of different combinations and concentrations of supplementary salts on the total concentration of minerals in fruit dry matter were observed [190].

Results of sensorial testing experiments showed that fruit from high EC-treated plants with $\mathrm{NaCl}$ enhanced the sensory evaluation of sweetness of tomato fruit and improved the overall flavour intensity of tomato fruit $[53,154]$, while $\mathrm{NaCl} / \mathrm{KCl}$ or $\mathrm{NaCl}$ increased the sensory evaluation of firmness but had minimal effects on the sensory evaluation of acidity of tomato fruit [53]. Nevertheless, excessive concentrations of $\mathrm{NaCl}$ in the nutrient solution due to poor water quality, may depress nutrient-ion activities and produce extreme ratios of $\mathrm{Na}^{+}: \mathrm{Ca}^{2+}, \mathrm{Na}^{+}: \mathrm{K}^{+}, \mathrm{Ca}^{2+}: \mathrm{Mg}^{2+}$, and $\mathrm{Cl}^{-}: \mathrm{NO}_{3}^{-}$[75]. As a result, the plant becomes susceptible to osmotic and specific-ion injury as well as to nutritional disorders that may result in reduced yield and quality. The depressing effects of $\mathrm{NaCl}$ salinity on the tissue $\mathrm{N}, \mathrm{P}, \mathrm{K}, \mathrm{Ca}, \mathrm{Mg}, \mathrm{S}$ and micronutrient concentrations were reviewed recently by Grattan and Grieve [75].

A substantial body of information in the literature indicates that the acceptable ion threshold in the plant rooting environment depends on the rate of absorption by the plant which depends upon the environmental factors and cultural practices. Tomato salinity studies vary drastically at both spatial and temporal levels, and different thresholds have been reported by several scientists. For instance, it has been reported that the maximum concentration acceptable in the rooting environment of tomato plants is $12 \mathrm{mmol}$ for sodium and $12 \mathrm{mmol}$ for chloride [169], while others established this threshold at $37 \mathrm{mM} \mathrm{NaCl}\left(6.2 \mathrm{mS} \cdot \mathrm{cm}^{-1}\right)$ [4]. We found no negative effect on fruit quality and yield at $25 \mathrm{mM} \mathrm{NaCl}$ (unpublished data). Addition of $22 \mathrm{mM} \mathrm{Na}\left(5.5 \mathrm{mS} \cdot \mathrm{cm}^{-1}\right)$ to the nutrient solution did not reduce fruit yield but increased the percentage of first class fruits [5]. A concentration of $67 \mathrm{mM} \mathrm{Na}\left(9.8 \mathrm{mS} \cdot \mathrm{cm}^{-1}\right)$ had little if any effect on fruit BER incidence. When $\mathrm{NaCl}, \mathrm{KCl}$ or $\mathrm{CaCl}_{2}$ was used to increase the $\mathrm{EC}$, the increase in the $\mathrm{Cl}^{-}$concentration $(8-13 \mathrm{mM}$ as compared to $3 \mathrm{mM})$ in the nutrient solution stimulated the absorption of $\mathrm{Ca}^{2+}$ and reduced BER incidence $[48,49]$ but increased the number of fruit with gold speck injury $[144,145]$. Thus, a threshold of $7.5 \mathrm{mM} \mathrm{Cl}$ in the rooting zone has been established to prevent this disorder [186]. Furthermore, Ho and Adams [89] suggested that substituting $\mathrm{NO}_{3}-\mathrm{N}$ with $\mathrm{KCl}, \mathrm{NaCl}$ or $\mathrm{CaCl}_{2}$ does not affect fruit quality if the minimal concentration of $\mathrm{NO}_{3}-\mathrm{N}$ in the nutrient solution is $120 \mathrm{mg} \cdot \mathrm{L}^{-1}$ and the $\mathrm{K}: \mathrm{N}$ ratio is kept between 2 and 4 .

The use of $\mathrm{NH}_{4}$ as a nitrogen source can increase plant growth and fruit sugars content but decreases fruit size and marketable yield due to a reduction of calcium and magnesium absorption and an increase in the number of fruit affected by BER [84, 95, 157]. Generally, nitrogen supply in the form of $\mathrm{NH}_{4}$ should be lower than $10 \%$ of total nitrogen in order to minimise the susceptibility of fruit to BER [8] and fruit with gold specks [147, 184]. Recently, significant interaction has been reported between $\mathrm{NH}_{4}$ concentration and the night-time salinity [159]. The use of high salinity during the night when $25 \%$ of total nitrogen was as $\mathrm{NH}_{4}$, compared to $0 \%$ of total nitrogen as $\mathrm{NH}_{4}$, reduced marketable yield and the harvest ratio, and increased fruit firmness at the fully ripe stage and BER incidence. This interaction may be explained by the fact that plant accumulates more $\mathrm{Na}^{+}$ 
and $\mathrm{Cl}^{-}$and less $\mathrm{Ca}^{2+}$ and $\mathrm{K}^{+}$as the $\mathrm{NH}_{4}^{+}: \mathrm{NO}_{3}{ }^{-}$ratio increases [75].

The influence of irrigation with $\mathrm{CO}_{2}$-enriched water on plant development and yield has been reviewed [59]. Recently, studies [38, 39] showed that elevated rhizosphere dissolved inorganic carbon (DIC) under salinity stress stimulated tomato growth and was related to the site of $\mathrm{NO}_{3}{ }^{-}$reduction (root for salt-stressed plants) and higher $\mathrm{NO}_{3}^{-}$uptake [41]. Under these conditions growth may also be improved due to partial closure of the stomata (reduction of water loss) without significant impact on the photosynthate availability [39]. Addition of $5.68 \mathrm{mM} \mathrm{KHCO}_{3}$ per $\mathrm{dm}^{3}$ of the standard nutrient solution increased glucose and fructose in tissue (pericarp + locules) content of unripened green fruit from 34 to $46 \%$ and of mature red fruit from 23 to $30 \%$, and organic acid content by $27-36 \%$ [25]. The effect of bicarbonate on fruit quality is more profound under high salinity conditions. An EC of 6-7 $\mathrm{mS} \cdot \mathrm{cm}^{-1}$ together with a bicarbonate supply can increase the accumulation of total solids in the fruit [66]. Thus, increasing DIC concentration under saline condition of soilless growing systems where the DIC level is really low $(<1000 \mu \mathrm{M})$ compared to soil rhizosphere $(2000-5000 \mu \mathrm{M})$, might offset the negative effect of salt on plant growth and yield, and improve fruit quality.

\subsection{EC management}

Growing systems that recirculate the nutrient solution are attractive because they couple savings in water and fertilisers with decreased leaching [171]. However, the longer irrigation water is collected and re-used, the higher the concentration of salts. Controlling the concentration of the nutrient solution according to the greenhouse climate $[108,115]$ and the potential evapotranspiration $[142,193]$ may reduce the flushing rate and improve synchronisation of nutrient demand and nutrient supply, thereby decreasing the incidence of osmotic and specificion injury and increasing fruit quality. The nutrient solution concentration should be lowered at high temperatures to reduce nutrient losses in open irrigation systems and to prevent salt accumulation in closed irrigation systems [108]. However, sudden dramatic changes to root zone EC can have a negative effect on root and plant growth as well as on fruit quality. Thus, a diurnal-ECvariation strategy supplying low EC feed solution during the active plant growth period and a high EC solution in the afternoon and night might be used to keep a constant 24-h EC at the root level resulting in an improved fruit size and quality [82]. Nevertheless, inclusion of available knowledge on transpiration, ion uptake and parti- tioning in relation to greenhouse climate and cultural practices, into a fertigation model is necessary to control the leaching fraction and the nutrient supply based on the EC of the nutrient solution [109].

Studies conducted to improve tomato fruit quality with intermittent salinity stress have not been conclusive $[10,140]$. Nevertheless, for a summer/autumn tomato crop, normal day-time EC with high night-time EC (2/8) can be useful to improve tomato fruit quality (soluble sugar and acid content), without significant production losses [137]. Interesting results were also reported by Van Ieperen [179]. In spring and summer, he observed that a day/night salinity level of $1 / 9$ increased yield by $20 \%$, and reduced BER (from $2.2-3.0 \%$ to $0.4-0.6 \%$ ) compared to a similar $24 \mathrm{~h}$ average EC ( $5 / 5$ control treatment). In addition, dry-matter distribution towards the fruit was increased at 1/9 compared with 5/5, while drymatter percentage of the harvested fruit was slightly lower at $1 / 9$ compared with $5 / 5$. Contrary to some authors [10,57] but in agreement with others [7, 73], differences in yield were not only due to differences in fruit water content but also due to a change in the dry weight per fruit. In general, the effect of day-time EC proved to be more important than of the night-time EC [11, 137, 179], because a larger proportion of water and nutrients is taken up at day, and both are hampered by high salinity [55].

Under low or moderate EC, calcium application might be a key factor in the reduction of fruit with BER. For example, weekly foliar $\mathrm{CaCl}_{2}\left(6.5 \mathrm{~g} \cdot \mathrm{L}^{-1}\right)$ spraying reduced the proportion of fruit with BER by $33-40 \%$, while bi-weekly cluster (0-21 day-old) calcium spraying reduced the proportion of fruit with BER by $68-98 \%$ [52]. In addition, weekly applications of boron and boron*calcium (Borax 1.5-3 $\mathrm{g} \cdot \mathrm{L}^{-1}, \mathrm{CaCl}_{2} 6.5 \mathrm{~g} \cdot \mathrm{L}^{-1}$ ) done on 40 to 60 day-old fruits, reduced the fruit weight with cuticle cracking (CC) by $15 \%$ and $18 \%$, respectively, compared to the water control. Moreover, these two treatments reduced by $50 \%$ the CC severity and increased the marketable fruit yield [102].

\section{CONCLUSION}

In the face of a global market economy, obtaining high yields of tomato fruit of very high quality and flavor is essential for ensuring consumer satisfaction and for the success of the greenhouse industry. Relationships between greenhouse environment, salinity and mineral nutrition of the tomato plant are extremely complex. Under excessive substrate salinity conditions, plant performance, expressed as crop yield and product quality, may be adversely affected by salinity-induced nutritional 
disorders. These disorders may result from an osmotic effect as well as the influence of salinity on nutrient availability, competitive uptake, and transport or partitioning within the plant. Appropriate salinity and ionthresholds should not be generalised because they vary according to the quality parameters and interactions between cultivars, climatic factors (light, temperature, VPD, $\mathrm{CO}_{2}$ ), composition and concentration of the nutrient solution, crop management, as well as the type of growing media and irrigation system (open or closed). During the summer season, salinity-induced nutritional disorders are aggravated in a greenhouse environment with high transpirational demands prevailing under high light and temperature, and low ambient humidity. In fact, the ratio of nutrient uptake to water uptake is strongly affected by temperature resulting mainly by increased transpiration as a result of increased VPD [108].

A way to improve organoleptic and nutraceutic qualities of greenhouse tomato fruit without yield reduction is to maintain proper environmental parameters in the greenhouse (light, temperature, humidity, $\mathrm{CO}_{2}$ enrichment) and to implement new growing methods (higher EC, optimum irrigation and nutrient solution, calcium and boron fruit application). However, synergistic and antagonistic effects of climate and cultural factors occur, and more knowledge is required to optimise tomato fruit quality. Very little attention has been given to the influence of salinity and environmental factor interactions on fruit flavour and health benefit. Better knowledge of the spatial and temporal changes of the status of water and nutrients both in the plant and in the root environment is essential to guarantee an optimal growth, yield and fruit quality under different greenhouse growing conditions. Thus, simulation models of water and nutrient uptake of greenhouse tomato proposed by different authors [107, $108,115]$ provide keytools to improve both the tactical and operational fertigation management. For example, at the short time-scale level, $\mathrm{N}$ supply to tomato should be managed separately from water supply since water and $\mathrm{N}$ uptakes were uncoupled under conditions where VPD was manipulated [115]. Increasing tomato fruit quality and yield can also be achieved by developing an appropriate and reliable irrigation management for different substrates based on the monitoring of moisture (TDR) and EC directly in the media.

From a cultural and physiological point of view, research should be conducted with the aim of: (1) optimising the greenhouse climate; (2) optimising the absorption of nutrients and their partitioning; (3) co-ordinating the supply of water, nutrients, and photoassimilates with the stage of development of plant organs in order to get products of very high quality [89]; (4) improving fruit unloading capacity and sink strength by a better understanding of the regulation of sucrose unloading and sugar storage to the fruit; and (5) providing physiological and biochemical knowledge on the metabolism of organoleptic and nutraceutic compounds in relation to their regulation and growth environment. These kinds of knowledge are esssential to develop predictive models for tomato quality management.

\section{REFERENCES}

[1] Abbott J.D., Peet M.M., Willits D.H., Gough R.E., Water management of greenhouse tomatoes, HortScience 20 (1985) 688-690.

[2] Abbott J.D., Peet M.M., Willits D.H., Sanders D.C., Gough R.E., Effects of irrigation frequency and scheduling on fruit production and radial fruit cracking in greenhouse tomatoes in soil beds and in soil-less medium in bags, Sci. Hortic. 28 (1986) 209-217.

[3] Adams F., Ionic concentrations and activities in soil solutions, Soil Sci. Soc. Am. Proc. 35 (1971) 420-436.

[4] Adams P., The test of raised salinity, The Grower (Suppl.) 107 (1987) 23-27.

[5] Adams P., Some responses of tomatoes grown in NFT to sodium chloride, Proc. 7th Int. Congr. on Soilless Culture, Flevoh, ISOSC, Wageningen, The Netherlands, 1989, pp. 59-71.

[6] Adams P., Effects of watering on the yield, quality and composition of tomatoes grown in bags of peat, J. Hortic. Sci. 65 (1990) 667-674.

[7] Adams P., Effects of increasing the salinity of the nutrient solution with major nutrients or sodium chloride on the yield, quality and composition of tomatoes grown in rockwool, J. Hortic. Sci. 66 (1991) 201-207.

[8] Adams P., Plant nutrition demystified, Acta Hort. 481 (1999) 341-344.

[9] Adams P., El-Gizawy A.M., Effect of salinity and watering level on the calcium content of tomato fruit, Acta Hort. 190 (1986) 253-259.

[10] Adams P., Ho L.C., Effects of constant and fluctuating salinity on the yield, quality and calcium status of tomatoes, J. Hortic. Sci. 64 (1989) 725-732.

[11] Adams P., Ho L.C., Effect of salinity on calcium transport in tomato, in: Van Beusichem M.L. (Ed.), Plant nutrition: physiology and applications, 1990, pp. 469-472.

[12] Adams P., Ho L.C., The susceptibility of modern tomato cultivars to blossom-end rot in relation to salinity, J. Hortic. Sci. 67 (1992) 827-839.

[13] Adams P., Ho L.C., Differential effects of salinity and humidity on growth and Ca status of tomato and cucumber grown in hydroponic culture, Acta Hort. 401 (1995) 357-363.

[14] Adams P., Ho L.C., Uptake and distribution of nutrients in relation to tomato fruit quality, Acta Hort. 412 (1995) $374-387$. 
[15] Al-Harbi A.R., Growth and nutrient composition of tomato and cucumber seedlings as affected by sodium chloride salinity and supplemental calcium, J. Plant Nutr. 18 (1995) 1403-1416.

[16] Al-Rawahy S.A., Stroehlein J.L., Pessarakli M., Effect of salt stress on dry matter production and nitrogen uptake by tomatoes, J. Plant Nutr. 13 (1990) 567-577.

[17] Alam S.M., Naqvi S.S.M., Azmi A.R., Effect of salt stress on growth of tomato, Pak. J. Sci. Ind. Res. 32 (1989) $110-113$.

[18] Atta-Aly M.A., Saltveit M.E., El-Beltagy A.S., Saline growing conditions induce ripening of the non-ripening mutant nor and rin tomato fruits but not of $\mathrm{Nr}$ fruit, Postharvest Biol. Technol. 13 (1998) 225-234.

[19] Auerswald H., Schwarz D., Kornelson C., Krumbein A., Brückner B., Sensory analysis (QDA), sugar and acid content and consumer acceptance of two types of tomato varieties hydroponically grown and effected by EC value of the nutrient solution, Sci. Hortic. 82 (1999) 227-242.

[20] Awad A.S., Edwards D.G., Campbell L.C., Phosphorus enhancement of salt tolerance in tomato, Crop Sci. 30 (1990) 123-128.

[21] Balibrea M.E., Santa Cruz A.M., Bolarin M.C., PerezAlfocea F., Sucrolityc activities in relation to sink strength and carbohydrate composition in tomato fruit growing under salinity, Plant Sci. 118 (1996) 47-55.

[22] Bakker J.C., Russeting (cuticle cracking) in glasshouse tomatoes in relation to fruit growth, J. Hortic. Sci. 63 (1988) 459-463.

[23] Belda R.M., Ho L.C., Salinity effects on the network of vascular bundles during tomato fruit development, J. Hortic. Sci. 68 (1993) 557-564.

[24] Belda R.M., Fenlon J.S., Ho L.C., Salinity effects on the xylem vessels in tomato fruit among cultivars with different susceptibility to blossom-end rot, J. Hortic. Sci. 71 (1996) 173-179.

[25] Bialczyk J., Lechowski Z., Libik A., Fruiting of tomato cultivated on medium enriched with bicarbonate, J. Plant Nutr. 19 (1996) 305-321.

[26] Bucheli P., Voirol E., de la Torre R., Lopez J., Rytz A., Tankksley S.D., Petiard V., Definition of nonvolatile markers for flavor of tomato (Lycopersicon esculentum Mill.) as tools in selection and breeding, J. Agric. Food Chem. 47 (1999) 659-664.

[27] Bucheli P., Lopez J., Voirol E., Petiard V., Tankksley S.D., Definition of biochemical and molecular markers (quality trait loci) for tomato flavor as tools in breeding, Acta Hort. 487 (1999) 301-306.

[28] Caro M., Cruz V., Cuartero J., Estan M.T., Bolarin M.C., Salinity tolerance of normal and cherry tomato cultivars, Plant and Soil 136 (1991) 249-255.

[29] Carvajal M., Martinez V., Cerda A., Influence of magnesium and salinity on tomato plants grown in hydroponic culture, J. Plant Nutr. 22 (1999) 177-190.
[30] Chen Z., Miller A.R., Steroid alkaloids in Solanaceous vegetable crops: Chemistry, biochemistry, distribution, horticulture and toxicology, Hortic. Rev. 25 (2001) in press.

[31] Cho J.Y., Lee B.S., Park S.G., Chung S.J., Effect of $\mathrm{NaCl}$ in nutrient solution during seedling stage and after transplanting on the fruit quality of aeroponically grown tomato plants, Lycopersicon esculentum L., Proc. 7th ISHS Symp. on Vegetable Quality, Seoul, Korea, 1997, pp. 240-244.

[32] Chrétien S., Gosselin A., Dorais M., High electrical conductivity and radiation-based water management improve fruit quality of greenhouse tomatoes grown in rockwool, HortScience 35 (2000) 627-631.

[33] Clarkson D.T., Hanson J.B., The mineral nutrition of higher plants, Annu. Rev. Plant Physiol. 31 (1980) 239-298.

[34] Clinton L.S.K., Lycopene: chemistry, biology, and implications for human health and disease, Nutr. Rev. 56 (1998) 35-51.

[35] Cornish P.S., Use of high electrical conductivity of nutrient solution to improve the quality of salad tomatoes (Lycopersicon esculentum) grown in hydroponic culture, Aust. J. Exp. Agric. 32 (1992) 513-520.

[36] Cortés C., Ayuso M.C., Palomares G., Cuartero J., Nuez F., Relationship between radial and concentric cracking of tomato fruit, Sci. Hortic. 21 (1983) 323-328.

[37] Cram W.J., Chloride accumulation as a homeostatic system: set points and perturbation, J. Exp. Bot. 34 (1983) 1484-1502.

[38] Cramer M.D., Lips S.H., Enriched rhizosphere $\mathrm{CO}_{2}$ concentrations can ameliorate the influence of salinity on hydroponically grown tomato plants, Physiol. Plant. 94 (1995) 425-432.

[39] Cramer M.D., Richards M.B., The effect of rhizosphere dissolved inorganic carbon on gas exchange characteristics and growth rates of tomato seedlings, J. Exp. Bot. 50 (1999) 79-87.

[40] Cramer M.D., Schierholt A., Wang Y.Z., Lips S.H., The influence of salinity on the utilization of root anaplerotic carbon and nitrogen metabolism in tomato seedlings, J. Exp. Bot. 46 (1995) 1569-1577.

[41] Cramer M.D., Savidov N., Lips S.H., The influence of enriched rhizosphere $\mathrm{CO}_{2}$ concentrations on $\mathrm{N}$ uptake and metabolism in NR-deficient and wild-type barley, Physiol. Plant. 97 (1996) 47-54.

[42] Cruz V., Tolerancia a la salinidad y criterios de selection en Lycopersicon Mill. spp., Ph.D. thesis, Universidad de Malaga, 1990, p. 484.

[43] Cuartero J., Soria T., Productividad de tomates cultivados en conditions salinas, Actas de Hortic. 16 (1997) 214-221.

[44] Cuartero J., Fernandez-Munoz R., Tomato and salinity, Sci. Hortic. 78 (1999) 83-125.

[45] Davies J.N., Effect of nitrogen, phosphorus and potassium fertilizers on the non-volatile organic acids of tomato fruit, J. Agric. Food Chem. 10 (1964) 665-673.

[46] Davies J.N., Hobson G.E., The constituents of tomato fruit - the influence of environment, nutrition, and genotype, Crit. Rev. Food Sci. Nutr. 15 (1981) 205-280. 
[47] De Koning A.N.M., Modelling development and dry matter distribution of tomato, Annu. Rep. Glasshouse Crops Research Station, Naaldwijk, The Netherlands, 1992, p. 34.

[48] De Kreij C., Blossom-end rot, Compte rendu de la réunion du 25 février, Cultilène, division d'Isover, St-Gobain, France, 1992.

[49] De Kreij C., Latest insights into water and nutrient control in soilless cultivation, Acta Hort. 408 (1995) 47-61.

[50] De Kreij C., Voogt W., Van Den Bos A.L., Baas R., Voedingsoplossingen voor de teelt van tomaat in gesloten teeltsystemen, Proefstation voor Bloemisterij en Glasgroente, Naaldwij, The Netherlands, VG2, 1997.

[51] Dorais M., Papadopoulos A.P., Ehret D.L., Turcotte G., Gosselin A., Can tomato fruit quality and flavor be controlled by EC and water management? International Society of Horticultural Science, Hydroponics and Growing Media Symposium, Halkidiki, Greece, August 31 to September 6, 1999, p. 76.

[52] Dorais M., Dorval R., Demers D.A., Micevic D., Turcotte G., Hao X., Papadopoulos A.P., Ehret D.L., Gosselin A., Improving tomato fruit quality by increasing salinity: effects on ion uptake, growth and yield, XXV International Horticultural Congress, Brussels August 2-7, 1998, Acta Hort. 511( 2000) 185-196.

[53] Dorais M., Papadopoulos A.P., Turcotte G., Hao X., Ehret D.L., Gosselin A., Control of tomato fruit quality and flavour by EC and water management, Greenhouse and Processing Crops Research Centre Annual Report, Harrow, ON, Canada, 2000, pp. 18-21.

[54] Drake B.D., Gonzalez-Meler M.A., Long S.P., More efficient plants: consequences of rising atmospheric $\mathrm{CO}_{2}$ ? Annu. Rev. Plant Physiol. 48 (1997) 609-639.

[55] Ehret D.L., Ho L.C., Effects of osmotic potential in nutrient solution on diurnal growth of tomato fruit, J. Exp. Bot. 37 (1986) 1294-1302.

[56] Ehret D.L., Ho L.C., Translocation of calcium in relation to tomato fruit growth, Ann. Bot. 58 (1986) 679-688.

[57] Ehret D.L., Ho L.C., The effect of salinity on dry matter partitioning and fruit growth in tomatoes grown in nutrient film culture, J. Hortic. Sci. 61 (1986) 361-367.

[58] El-Sherif A.F., Shata S.M., Youssef R.A., Response of tomato seedlings to zinc application under different salinity levels I. Dry matter, $\mathrm{Ca}, \mathrm{Mg}, \mathrm{K}$ and $\mathrm{Na}$ content, Egypt J. Hortic. 17 (1990) 131-142.

[59] Enoch H.Z., Olesen J.M., Plant response to irrigation with water enriched with carbon dioxide, New Phytol. 125 (1993) 249-258.

[60] Epstein E., Mineral nutrition of plants; principles and perspectives, Wiley, New York, 1972.

[61] Evans H.J., Sorger G., Role of mineral elements with emphasis on the univalent cations, Annu. Rev. Plant Physiol. 17 (1966) 47-76.

[62] Ferreyra R., Aljaro A., Ruiz R., Rojas L., Oster J.D., Behavior of 42 crop species grown in saline soils with high boron concentrations, Agric. Water Manage. 34 (1997) 111-124.
[63] Franscis A.R., Shetty T.K., Bhattacharya R.K., Modifying role of dietary factors on the mutagenicity of aflatoxin B1: in vitro effect of plant falvonoids, Mutat. Res. 222 (1989) 393-401.

[64] Frota J.N.E., Tucker T.C., Absortion rates of ammonium nitrate by red kidney beans under salt and water stress, Soil Sci. Soc. Am. J. 42 (1978) 753-756.

[65] Frydrych J., Factors affecting photosynthetic productivity of sweet pepper and tomatoes grown in $\mathrm{CO}_{2}$-enriched atmosphere, Acta Hort. 162 (1984) 271-278.

[66] Gao Z., Sagi M., Lips H., Assimilate allocation priority as affected by nitrogen compounds in the xylem sap of tomato, Plant Physiol. Biochem. 34 (1996) 807-815.

[67] Gao Z., Sagi M., Lips S.H., Carbohydrate metabolism in leaves and assimilate partitioning in fruits of tomato (Lycopersicon esculentum L.) as affected by salinity, Plant Sci. 135 (1998) 149-159.

[68] Gerster H., The potential role of lycopene for human health: Review article, J. Am. Coll. Nutr. 16 (1997) 109-126.

[69] Giovannucci E., Tomatoes, tomato-based products, lycopene, and cancer: review of the epidemiologic literature, J. Nat. Cancer Inst. 91 (1999) 317-331.

[70] Gonzalez-Fernandez J.J., Cuartero J., Fructificacion en dos especies de Lycopersicon cultivadas con sal, Actas de Hortic. 9 (1994) 41-47.

[71] Gormley T.R., Maher M.J., Tomato fruit quality: an interdisciplinary approach, Prof. Hortic. 4 (1990) 107-112.

[72] Gosselin A., Trudel M.J., Interactions between air and root temperatures on greenhouse tomato: II. Mineral composition of plants, J. Am. Soc. Hortic. Sci. 108 (1983) 905-909.

[73] Gough C., Hobson G.E., A comparison of the productivity, quality, shelf-life characteristics and consumer reaction to the crop from cherry tomato plants grown at different levels of salinity, J. Hortic. Sci. 65 (1990) 431-439.

[74] Grange R.L., Hand D.W., A review of the effects of atmospheric humidity on the growth of horticultural crops, J. Hortic. Sci. 62 (1987) 125-134.

[75] Grattan S.R., Grieve C.M., Salinity-mineral nutrient relations in horticultural crops, Sci. Hortic. 78 (1999) 127-157.

[76] Grierson D., Kader A.A., Fruit ripening and quality, in: Atherton J.G., Rudich J. (Eds.), The tomato crop: A scientific basis for improvement, Chapman and Hall, London, 1986, pp. 241-280.

[77] Grolier P., Rock E., The composition of tomato in antioxydants: variations and methodology, Proc. Tomato and Health Seminar. Pamplona, Spain, 25-28 May, 1998, pp. 87-94.

[78] Grunberg K., Fernandez-Munoz R., Cuartero J., Growth, flowering, and quality and quantity of pollen of tomato plants grown under saline conditions, Acta Hort. 412 (1995) 484-489.

[79] Gupta U.C., Jame Y.W., Campbell C.A., Leyshon A.J., Nicholaichuk W., Boron toxicity and deficiency: a review, Can. J. Soil Sci. 65 (1985) 381-409.

[80] Hao X., Papadopoulos A.P., Dorais M., Ehret D.E., Turcotte G., Gosselin A., Improving tomato fruit quality by 
raising the EC of NFT nutrient solutions and calcium spraying: effects on growth, photosynthesis, yield and quality, XXV International Horticultural Congress, Brussels, August 2-7, 1998, Acta Hort. 511 (2000) 213-224.

[81] Hao X., Papadopoulos A.P., Paine R., Effects of calcium and magnesium in nutrient solutions on growth, yield and quality of rockwool grown tomato, Greenhouse and Processing Crops Research Centre Annual Report, Harrow, ON, Canada, 2000, pp. 13-15.

[82] Hao X., Papadopoulos A.P., Vollans K., Effects of electrical conductivity (EC) and its diurnal changes in nutrient feedings on fruit yield and quality of greenhouse tomato grown in rockwool, Greenhouse and Processing Crops Research Centre Annual Report, Harrow, ON, Canada, 2000, pp. 116-117.

[83] Hayman G., The hair-like cracking of last season, Grower 107 (1987) 3-5.

[84] Ho L.C., The mechanism of assimilate partitioning and carbohydrate compartmentation in fruit in relation to the quality and yield of tomato, J. Exp. Bot. 47 (1996) 1239-1243.

[85] Ho L.C., Tomato, in: Zamski E., Schaffer A.A. (Eds.), Photoassimilate distribution in plants and crops: Source-sink relationships, Marcel Dekker, Inc., 1996, pp. 709-728.

[86] Ho L.C., The physiological basis for improving tomato fruit quality, Acta Hort. 487 (1999) 33-40.

[87] Ho L.C., Adams P., Effects of diurnal changes in the salinity of the nutrient solution on the accumulation of calcium by tomato fruit, Ann. Bot. 64 (1989) 373-382.

[88] Ho L.C., Adams P., The physiological basis for high fruit yield and susceptibility to calcium deficiency in tomato and cucumber, J. Hort. Sci. 69 (1994) 367-376.

[89] Ho L.C., Adams P., Nutrient uptake and distribution in relation to crop quality, Acta Hort. 396 (1995) 33-44.

[90] Ho L.C., Grange R.I., Picken A.J., An analysis of the accumulation of water and dry matter in tomato fruit, Plant Cell Environ. 10 (1987) 157-162.

[91] Ho L.C., Hand D.J., Fussell M., Improvement of tomato fruit quality by calcium nutrition, Acta Hort. 481 (1999) 463-468.

[92] Ho L.C., Belda R., Brown M., Andrews J., Adams P., Uptake and transport of calcium and the possible causes of blossom-end rot in tomato, J. Exp. Bot. 44 (1993) 509-518.

[93] Ho L.C., Adams P., Li X.Z., Shen H., Andrew J., Xu Z.H., Response of Ca-efficient and Ca-inefficient tomato cultivars to salinity in plant growth, calcium accumulation and blossom-end rot, J. Hortic. Sci. 70 (1995) 909-918.

[94] Hobson G.E., Pre- and post-harvest strategies in the production of high quality tomato fruit, Appl. Agric. Res. 3 (1988) 282-287.

[95] Hohjo M., Kuwata C., Yoshikawa K., Ito T., Effects of nitrogen form, nutrient concentration and $\mathrm{Ca}$ concentration on the growth, yield and fruit quality in NFT-tomato plants, Acta Hort. 396 (1995) 145-152.

[96] Holder R., Christensen M.H., The effects of electrical conductivity on the growth, yield and composition of cherry tomatoes grown on rockwool, Proc. 7 th Int. Congress on
Soilless Culture. ISOSC, Wageningen, Flevohof, 1989, pp. 213-228.

[97] Hsiao T.C., Lauchli A., Role of potassium in plantwater relations, Adv. Plant Nutr. 2 (1986) 281-312.

[98] Jackson W.A., Volk R.J., Role of potassium in photosynthesis and respiration, in: The role of potassium in agriculture, Am. Soc. Agric. Madison, WS, 1968, pp. 109-188.

[99] Janse J., Invloed van licht op de kwaliteit van tomaat en komkommer, Groenten en fruit 40 (1984) 28-31.

[100] Janse J., Goudspikkels bij tomaat; een oplosbaar probleem, Groenten en Fruit 43 (1988) 30-31.

[101] Janse J., Flavour of tomatoes, in: XXX. Vortragstagung der Deutschen Gesellschaft für Qualitätsforschung, Heilbronn, Deutschland, 27-28 März, 1995, pp. 179-194.

[102] Jobin-Lawler F., Dorais M., Simard K., Papadopoulos A.P., Gosselin A., Effects of solar radiation and boron fruit application on cuticle cracking of greenhouse tomato grown under artificial lighting, 4th International ISHS Symposium on Artificial Lighting, Quebec city, Canada, November 7-9, 2000, p. 49.

[103] Johnson R.W., Dixon M.A., Lee D.R., Water relations of the tomato fruit during growth, Plant Cell Environ. 15 (1992) 947-953.

[104] Jones J.B. Jr., Phosphorus toxicity in tomato plants: when and how does it occur? Commun. Soil Sci. Plant Anal. 29 (1998) 1779-1784.

[105] Kabu K.L., Toop E.W., Influence of soil temperature and potassium fertilization on magnesium content of tomato plants, Can. J. Plant Sci. 50 (1970) 740-742.

[106] Kader A.A., Effects of postharvest handling procedures on tomato quality, Acta Hort. 190 (1986) 209-221.

[107] Kläring H.-P., Schwarz D., Model-based control of concentration of nutrient solution in glasshouse tomato cultivation, Acta Hort. 507 (1999) 127-132.

[108] Kläring H.-P., Schwarz D., Heibner A., Control of nutrient solution concentration in tomato crop using models of photosynthesis and transpiration: A simulation study, Acta Hort. 450 (1997) 329-334.

[109] Kläring H.-P., Schwarz D., Cierpinski W., Control of concentration of nutrient solution in soilless growing systems, depending on greenhouse climate - Advantages and limitations, Acta Hort. 507 (1999) 133-139.

[110] Knight S.L., Rogers R.B., Smith M.A.L., Spomer L.A., Effects of $\mathrm{NaCl}$ salinity on miniature dwarf tomato "Micro-Tom": I. Growth analyses and nutrient composition, J. Plant Nutr. 15 (1992) 2315-2327.

[111] Krinsky N.I., Effects of carotenoids in cellular and animal systems, Am. J. Clin. Nutr. 53 (1991) 238S-246S.

[112] Krinsky N.I., Anticarcinogenic activities of carotenoids in animals and cellular systems, in: Emers I., Chance B. (Eds.), Free Radicals and Aging, Verlag, Basel, 1992, pp. 227-234.

[113] Läuchli A., Responses and adaptations of crops to salinity, Acta Hort. 190 (1986) 243-246. 
[114] Lea-Cox J.D., Syvertsen J.P., Salinity reduces water use and nitrate-N-use efficiency of citrus, Ann. Bot. 72 (1993) $47-54$.

[115] LeBot J., Adamowicz S., Robin P., Gary C., Modelling nitrate uptake by greenhouse tomato crops at the short and long time scales, Acta Hort. 456 (1998) 237-245.

[116] Leigh R.A., Wyn Jones R.G., A hypothesis relating critical potassium concentrations for growth to the distribution and functions of this ion in the plant cell, New Phytol. 97 (1984) 1-13.

[117] Li G.J., Xu Z.H., Dai D.L., Shou W.L., The effect of cultivars, electrical conductivity and harvest date on the storability of cherry tomato grown in soilless culture, Acta Agric. Zhejiangensis 11 (1999) 17-22.

[118] Li J.H., Gale J., Novoplansky A., Barak S., Volokita M., Response of tomato plants to saline water as affected by carbon dioxide supplementation. II. Physiological responses, J. Hortic. Sci. Biotechnol. 74 (1999) 238-242.

[119] Li J.H., Sagi M., Gale J., Volokita M., Novoplansky A., Response of tomato plants to saline water as affected by carbon dioxide supplementation. I. Growth, yield and fruit quality, J. Hortic. Sci. Biotechnol. 74 (1999) 232-237.

[120] Lin W.C., Glass A.D.M., The effects of $\mathrm{NaCl}$ addition and macronutrient concentration on fruit quality and flavor volatiles of greenhouse tomatoes, Acta Hort. 481 (1999) 487-493.

[121] Lopez J.B., Étude des effets des ions sulfates dans la solution nutritive sur la croissance, la physiologie, la nutrition minérale et la productivité de la tomate de serre, Thèse de doctorat, Univ. Laval, Québec, Canada, 1998.

[122] Lopez M.V., Satti S.M.E., Calcium and potassiumenhanced growth and yield of tomato under sodium chloride stress, Plant Sci. 114 (1996) 19-27.

[123] Maas E.V., Hoffman G.J., Crop salt tolerance: current assessment, J. of the Irrigation and Drainage Division, Am. Soc. Civil Eng. 103 (1977) 116-134.

[124] Maas E.V., Ogata G., Garber M.J., Influence of salinity on Fe, Mn, and Zn uptake by plants, Agron. J. 64 (1972) 793-795.

[125] Malundo T.M.M., Shewfelt R.L., Scott J.W., Flavor quality of fresh tomato (Lycopersicon esculentum Mill.) as affected by sugar and acid levels, Postharvest Biol. Technol. 6 (1995) 103-110.

[126] Marschner H., Mineral nutrition of higher plants, 2nd ed. Academic Press, London, 1995.

[127] Martinez V., Cerda A., Influence of N source on rate of $\mathrm{Cl}, \mathrm{N}, \mathrm{Na}$, and $\mathrm{K}$ uptake by cucumber seedlings grown in saline conditions, J. Plant Nutr. 12 (1989) 971-983.

[128] Massey D.M., Hayward A.C., Winsor G.W., Some responses of tomatoes to salinity in nutrient film culture, in: Glasshouse Crops Res. Inst. Annu. Rep. 1984, pp. 60-62.

[129] McAvoy R.J., Fruit cracking in greenhouse tomatoes, Connecticut Greenhouse Newsletter 178 (1994) 21-28.

[130] McAvoy R., Don't let your tomatoes crack up - Here's how to prevent those unsighty and profit-robbing-cracks on fruit, Am. Veget. Grower, August, 1995, pp. 46-47.
[131] Minamide R.T., Ho L.C., Deposition of calcium compounds in tomato fruit in relation to calcium transport, J. Hortic. Sci. 68 (1993) 755-762.

[132] Mitchell J.P., Shennan C., Grattan S.R., May D.M., Tomato fruit yields and quality under water deficit and salinity, J. Am. Soc. Hortic. Sci. 116 (1991) 215-221.

[133] Mizrahi Y., Effect of salinity on tomato fruit ripening, Plant Physiol. 69 (1982) 966-970.

[134] Mizrahi Y., Arad S., Zohar R., Salinity as a possible means of improving fruit quality in slow-ripening tomato hybrids, Acta Hort. 190 (1986) 223.

[135] Mizrahi Y., Taleisnik E., Kagan-Zur V., Zohar Y., Offenbach R., Matan E., Golan R., A saline irrigation regime for improving tomato fruit quality without reducing yield, J. Am. Soc. Hortic. Sci. 113 (1988) 202-205.

[136] Nederhoff E.M., Effects of $\mathrm{CO}_{2}$ concentration on photosynthesis, transpiration and production of greenhouse fruit vegetable crops, Dissertation, Wageningen, The Netherlands, 1994.

[137] Nederhoff E., Effects of different day/night conductivities on blossom-end rot, quality and production of greenhouse tomatoes, Acta Hort. 481 (1999) 495-502.

[138] Ness A.R., Powles J.W., Fruit and vegetables, and cardiovascular disease: A review, Int. J. Epidemiol. 26 (1997) $1-13$.

[139] Niazi B.H., Ahmed T., Effect of sodium chloride and zinc on the growth of tomato. II. Uptake of ions, Geobios 11 (1984) 155-160.

[140] Niedziela C.E. Jr., Nelson P.V., Willits D.H., Peet M.M., Short-term salt-shock effects on tomato fruit quality, yield, and vegetative prediction of subsequent fruit quality, J. Am. Soc. Hortic. Sci. 118 (1993) 12-16.

[141] Nonami H., Fukuyama T., Yamamoto M., Yang L., Hashimoto Y., Ito T., Tognoni F., Namiki T., Nukaya A., Maruo T., Blossom-end rot of tomato plants may not be directly caused by calcium deficiency, Acta Hort. 396 (1995) $107-114$

[142] Norrie J., Graham M.E.D., Gosselin A., Potential evapotranspiration as a means of predicting irrigation timing in greenhouse tomatoes grown in peatbags, J. Am. Soc. Hortic. Sci. 119 (1994) 163-168.

[143] Norrie J., Graham M.E.D., Charbonneau J., Gosselin A., Impact of irrigation management of greenhouse tomato: Yield, nutrition, and salinity of peat substrate, Can. J. Plant Sci. 75 (1995) 497-503.

[144] Nukaya A., Voogt W., Sonneveld C., Effects of $\mathrm{NO}_{3}$, $\mathrm{SO}_{4}$ and $\mathrm{Cl}$ ratios on tomatoes grown in recirculating system, Acta Hort. 294 (1991) 297-304.

[145] Nukaya A., Voogt W., Sonneveld C., Effects of $\mathrm{NO}_{3}$, $\mathrm{SO}_{4}$ and $\mathrm{Cl}$ ratios on tomatoes grown in recirculating system, Acta Hort. 303 (1992) 91-98.

[146] Nukaya A., Goto K., Jang H., Kano A., Ohkawa K., Effect of $\mathrm{K}-\mathrm{Ca}$ ratio in the nutrient solution on the incidence of blossom-end rot and gold specks on tomato fruit grown in rockwool, Acta Hort. 396 (1995) 123-130. 
[147] Nukaya A., Goto K., Jang H., Kano A., Ohkawa K., Effect of $\mathrm{NH}_{4}-\mathrm{N}$ level in the nutrient solution on the incidence of blossom-end rot and gold specks on tomato fruit grown in rockwool, Acta Hort. 401 (1995) 381-388.

[148] Pearce B.D., Grange R.I., Hardwick K., The growth of young tomato fruit. II. Environmental influences on glasshouse crops grown in rockwool or nutrient film, J. Hortic. Sci. 68 (1993) 13-23.

[149] Peet M.M., Fruit cracking in tomato, HortTechnology 2 (1992) 216-223.

[150] Peet M.M., Willits D.H., Role of excess water in tomato fruit cracking, HortScience 30 (1995) 65-68.

[151] Pérez-Alfocea F., Balibrea M.E., Santa Cruz A., Estan M.T., Agronomical and physiological characterization of salinity tolerance in a commercial tomato hybrid, Plant and Soil 180 (1996) 251-257.

[152] Pessarakli M., Tucker T.C., Uptake of nitrogen-15 by cotton under salt stress, Soil Sci. Soc. Am. J. 49 (1985) 149-152.

[153] Pessarakli M., Tucker T.C., Dry matter yield and nitrogen-15 uptake by tomatoes under sodium chloride stress, Soil Sci. Soc. Am. J. 52 (1988) 698-700.

[154] Petersen K.K, Willumsen J., Kaack K., Composition and taste of tomatoes as affected by increased salinity and different salinity sources, J. Hortic. Sci. Biotechnol. 73 (1998) 205-215.

[155] Petro-Turza M., Flavor of tomato and tomato products, Food Rev. Int. 2 (1986) 309-351.

[156] Phatak S.C., Wittwer S.H., Teubner F.G., Top and root temperature effects on tomato flowering, Proc. Am. Soc. Hortic. Sci. 88 (1966) 527-531.

[157] Pivot D., Reist A., Gillioz J.-M., Water quality, climatic environment and mineral nutrition of tomato (Lycopersicon esculentum) in closed soilless cropping system, Acta Hort. 458 (1997) 207-214.

[158] Rodriguez P., Dell'Amico J., Morales D., SanchezBlanco M.J., Alarcon J.J., Effects of salinity on growth, shoot water relations and root hydraulic conductivity in tomato plants, J. Agric. Sci. 128 (1997) 413-444.

[159] Sandoval-Villa M., Wood C.W., Guertal E.A., Effects of nitrogen form, nighttime nutrient solution strenght, and cultivar on greenhouse tomato production, J. Plant Nutr. 22 (1999) 1931-1945.

[160] Scholberg J.M.S., Locascio S.J., Growth response of snap bean and tomato as affected by salinity and irrigation method, HortScience 34 (1999) 259-264.

[161] Schwarz M., Gale J., Growth responses to salinity at high levels of carbon dioxide, J. Exp. Bot. 35 (1984) 193-196.

[162] Shalhevet J., Maas E.V., Hoffman G.J., Ogata G., Salinity and hydraulic conductance of roots, Physiol. Plant. 38 (1976) 224-232.

[163] Shannon M.C., Grieve C.M., Tolerance of vegetable crops to salinity, Sci. Hortic. 78 (1999) 5-38.

[164] Shi Z.-Q., Turcotte G., Gosselin A., Papadopoulos A.P., Dorais M., Effects of different EC management on yield, quality and nutraceutical properties of tomato grown in rock- wool, 4th ISHS International Symposium on Artificial Lighting, Acta Hort. 2001 (in press).

[165] Solimann M.S., Doss M., Salinity and mineral nutrition effects on growth and accumulation of organic and inorganic ions in two cultivated tomato varieties, J. Plant Nutr. 15 (1992) 2789-2799.

[166] Song J.Q., Fujiyama H., Difference in response of rice and tomato subjected to sodium salinization to the addition of calcium, Soil Sci. Plant Nutr. 42 (1996) 503-510.

[167] Sonneveld C., The salt tolerance of greenhouse crops, Neth. J. Agric. Sci. 36 (1988) 63-73.

[168] Sonneveld C., Welles G.W.H., Yield and quality of rockwool-grown tomatoes as affected by variations in ECvalue and climatic conditions, Plant and Soil 111 (1988) $37-42$.

[169] Sonneveld C., Van Der Burg A.M.M., Sodium chloride salinity in fruit vegetable crops in soilless culture, Neth. J. Agric. Sci. 39 (1991) 115-122.

[170] Soria T., Cuartero J., Tomato fruit yield and water consumption with salty water irrigation, Acta Hort. 458 (1997) 215-219.

[171] Stanghellini C., van Meurs W.Th.M., Corver F., Van Dullemen E., Simonse L., Combined effect of climate and concentration of the nutrient solution on a greenhouse tomato crop. II: Yield quantity and quality, Acta Hort. 458 (1998) 231-237.

[172] Steinmetz K.A., Potter J.D., Vegetables, fruits and cancer prevention: A review, J. Am. Diet Assoc. 96 (1996) $1027-1039$.

[173] Stevens M.A., Tomato quality: potential for developing cultivars with improved flavor, Acta Hort. 93 (1979) 317-329.

[174] Stevens M.A., Inheritance of tomato fruit quality components, Plant Breed. Rev. 4 (1986) 273-311.

[175] Stevens M.A., Rick C.M., Genetics and breeding, in: Atherton J.G., Rudich J. (Eds.), The tomato crop. A scientific basis for improvement, Chapman and Hall, London, 1986, pp. 35-109.

[176] Suhayda C.G., Giannini J.L., Briskin D.P., Shannon M.C., Elestrostatic changes in Lycopersicon esculentum root plasma membrane resulting from salt stress, Plant Physiol. 93 (1990) 471-478.

[177] Tüzel Y., Ul M.A., Tuzel I.H., Cockshull K.E., Gul A., Effects of different irrigation intervals and rates on spring season glasshouse tomato production: II. Fruit quality, 2nd Symp. Protected Cultivation of Solanacea in mild winter climates, Adana, Turkey 366 (1993) 389-396.

[178] Van Gnuchten M.T., Analyzing crop salt tolerance data: model description and user's manual. Research report 120. USDA Agr. Res. Ser., US Salinity Laboratory, Riverside, CA, 1983, p. 50.

[179] Van Ieperen W., Effects of different day and night salinity levels on vegetative growth, yield and quality of tomato, J. Hortic. Sci. 71 (1996) 99-111.

[180] Verkerke W., Schols M., The influence of EC level and specific nutrients on the firmness, taste and yield of tomato, Glasshouse Crops Res. Stat., Naaldwijk, 1992, p. 37. 
[181] Verkerke W., Gielesen C.J.M., Engelaan-Hokken L.T., Development of fruit firmness during growth period, Glasshouse Crops Res. Stat., Naaldwijk, 1991, p. 35.

[182] Verma A.K., Johnson J.A., Gould M.N., Tanner M.A., Inhibition of 7,12-dimethylbenz(a)anthracene and Nnitrosomethylurea induced rat mammary cancer by dietary flavonol quercetin, Cancer Res. 48 (1988) 5754-5788.

[183] Vonk Noordegraaf C., Welles G.W.H., Product quality, in: Bakker J.C., Bot G.P.A., Challa H., Van de Braak N.J. (Eds.), Greenhouse climate control; an integrated approach, Wageningen Pers. Wageningen, The Netherlands, 1995, pp. 92-97.

[184] Voogt W., Onderzoek naar de interacties bij de opname van voedingselementen, Glasshouse Crops Res. Stat., Naaldwijk, 1987, pp. 38-39.

[185] Voogt W., The growth of beefsteak tomato as affected by K/Ca ratios in the nutrient solution, Acta Hort. 222 (1987) 155-165.

[186] Voogt W., $\mathrm{NO}_{3} / \mathrm{Cl}$ ratios with beefsteak tomatoes, Glasshouse Crops Res. Stat., Naaldwijk, 1992, p. 14.

[187] Voogt W., Nutrient uptake of year round tomato crops, Acta Hort. 339 (1993) 99-112.

[188] Voogt W., Sonneveld C., Nutrient management in closed growing systems for greenhouse production, in: Goto E. (Ed.), Plant production in closed ecosystems, Kluwer Academic Publishers, 1997, pp. 83-102.

[189] Welles G.W.H., Janse J., Peron J.Y., L'influence des techniques modernes de production et des variétés sur la qualité analytique des légumes de serre, PHM Rev. Hortic. 324 (1992) 43-54.
[190] Willumsen J., Petersen K.K., Kaack K., Yield and blossom-end rot of tomato as affected by salinity and cation activity ratios in the root zone, J. Hortic. Sci. 71 (1996) 81-98.

[191] Winsor G.W., Baker A.M.A., Effects of nutrition on the composition and quality of field-grown tomatoes, Annu. Rep. Glasshouse Crops Research Institute, 1982, pp. 68-71.

[192] Xu H.L., Gauthier L., Gosselin A., Responses of the photosynthetic rate to photon flux density in tomato plants affected by high electrical conductivity of nutrient solution and low water content in substrate, Photosynthetica 30 (1994) 279-286.

[193] Xu H.L., Gauthier L., Gosselin A., Effects of fertigation management on photosynthesis in tomato plants grown in peat, rockwool and NFT, Sci. Hortic. 63 (1995) 11-12.

[194] Xu H.L., Gauthier L., Gosselin A., Greenhouse tomato photosynthetic acclimation to water deficit and response to salt accumulation in the substrate, J. Jap. Soc. Hortic. Sci. 65 (1997) 777-784.

[195] Xu H.L., Wang R., Gauthier L., Gosselin A., Tomato leaf photosynthetic responses to humidity and temperature under salinity and water deficit, Pedosphere 9 (1999) 105-112.

[196] Yelle S., Gosselin A., Trudel M.-J., Effets à long terme de l'enrichissement carboné sur la tomate de serre cultivée avec ou sans éclairage d'appoint, Can J. Plant Sci. 67 (1987) 899-907.

[197] Yelle S., Beeson R.C., Trudel M.-J., Gosselin A., Duration of $\mathrm{CO}_{2}$ enrichment influences growth, yield, and gas exchange of two tomato species, J. Am. Soc. Hortic. Sci. 115 (1990) 52-57.

To access this journal online: www.edpsciences.org 